\author{
K.P. Mussina ${ }^{1, *}$, D.G. Mamrayeva ${ }^{2}$, M. Lemanowicz ${ }^{3}$ \\ ${ }^{1}$ L.N. Gumilyov Eurasian National University, Kazakhstan \\ ${ }^{2}$ Karagandy University of the name of academician E. A. Buketov, Kazakhstan \\ ${ }^{3}$ Szkoła Główna Gospodarstwa Wiejskiego, Poland \\ ${ }^{1}$ kamshatmussina@mail.ru, ${ }^{2}$ dina2307@mail.ru, ${ }^{3}$ marzena_lemanowicz@sggw.pl \\ ${ }^{1}$ http://orcid.org/0000-0002-6772-6338, ${ }^{2}$ http://orcid.org/0000-0001-8508-7317, \\ ${ }^{3}$ https://orcid.org/0000-0002-5114-9185
}

\title{
Digitalization in the tourism industry of Kazakhstan
}

\begin{abstract}
Object: The article substantiates the need to use Internet technologies for the development of the tourism industry of Kazakhstan at the present stage, since tourism industry is characterized by a variety of intermediary schemes, so the need for using Internet technologies is increasing here. In particular, the authors pursue a goal to research the specifics of digitalization in the field of tourism and current problems limiting contribution of digitalization to increasing the competitiveness of the industry.

Methods: Such general scientific methods as statistical analysis, content analysis were employed for conducting the current research.

Findings: The article describes key areas of digital transformation of the tourism industry in the era of the digital economy, and also shows the advantages of digital transformation for the tourism industry, which are to deepen the knowledge of the tourists based on the provision of detailed information about places of recreation and travel; reduction of time for entry and exit of information, management and administrative processes.

Conclusions: This paper analyzes the current state of the tourism sector in Kazakhstan, presents the results of conducted analysis on ICT readiness in the context of Kazakhstani tourism industry. The perspective impact of digitalization on this industry is also considered.
\end{abstract}

Keywords: digitalization, tourism development, ICT, Kazakhstan, tourism industry, Tourism4.0, TTCI.

\section{Introduction}

Tourism, positioned as a priority sector in the economy of the Republic of Kazakhstan, can have a positive impact on addressing not only economic problems, but also on achieving a social goal, as well as protecting the environment. Tourism, especially in Kazakhstan with all its natural diversity and cultural heritage, can make a significant contribution to the growth of employment and further economic development.

Over the past years, the tourism sector has had an increasing impact on the economic development of Kazakhstan. Travel and tourism industry GDP in 2018 amounted to US \$2,998.4 million. According to preliminary estimates, in 2019, the share of tourism in the GDP reached 1.8 percent(Schwab, 2019).

According to the official statistics of the Republic of Kazakhstan, in 2018 the number of foreign citizens visiting the republic with tourist purposes amounted to 8789314 people. The main flow of foreign tourists came from CIS countries (Uzbekistan, Kyrgyz Republic, Russia), and from far abroad (Turkey, Germany, China, the USA, India, South Korea, etc.). At the same time, if the number of inbound tourists traveling to Kazakhstan has been steadily increasing since 2014 from 6332734 to the current amount. The number of outbound tourists amounted to 10646241 thousand people in 2018, including 1979431 for business and professional purposes, and 8666810 for personal purposes(Statistics Committee of the Ministery of National Economy of the Republic of Kazakhstan, 2019).

According to latest statistics available the average number of employees engaged in tourism sector in 2018 amounted to 44,6 thousand people. The average monthly salary of one employee in the tourism sector in 2018 varied from 86510 for the organizations of leisure, entertainment, culture and sports to 124217 tenge for accommodation services.

In modern conditions, the data presented in digital form are a key factor in the development of the economy of the 21 st century. In this regard, IT-technologies play a primary role.

According to the World Digital Competitiveness Ranking prepared by International Institute for Management Development (IMD) Kazakhstan has improved its position by three places in 2019, occupying thirty

\footnotetext{
* Corresponding author.

E-mail address: kamshatmussina@mail.ru
} 
fifth position out of 63 countries considered. This improvement became possible due to positive changes in different sub-indices, including "Training and education" (No 1), "Business agility" (No 15), "Regulatory framework" (No 16), and finally "Adaptive attitudes" (No 39) (Brits \& Cabolis, 2019).

The rapid development of the digital economy in the world provides increased competitiveness of states, industries, enterprises. The ubiquitous level of digitalization entails significant changes in the process of organizing a business. Today's trend is a digital transformation that affects all areas, focused on the global use of digital technologies in the activities of economic entities, the formation of the information society and the digital economy as a whole (Tashenova, Babkin, \& Mamrayeva, 2019).

\section{Literature Review}

One of the trends in the development of the global tourism industry at the present stage is proliferation of Internet technologies, in other words, the modern development of tourism is taking place in a digital context. The digitalization process has not bypassed the tourism industry itself. Digitalization in tourism is aimed at making the tourism business not only more flexible, consistent with current realities, but also more competitive in modern conditions. Digitalization of the hospitality industry helps to ensure a situation where customers get excellent results, and the owners of travel companies get higher incomes.

In recent decades, studies devoted to the introduction of digital technologies has received wide coverage. In 1995, the professor of the Massachusetts Institute of Technology N. Negroponte laid the foundation for researches in this domain (Negroponte, 1995; Negroponte, 2010). The basis of his research constitutes to the juxtaposition of traditional and digital economies with the intensive development of information and communication technologies. For the digital economy, the transition from the third industrial revolution to the fourth industrial revolution is intrinsic. The digital economy reflects the radical changes in the second half of the 20th century that were made possible in a result of digital computing and communication technologies advancement (Doucek, Fischer, \& Novotný, 2017; Singh, 2005).

Digital economy refers to an economy that is directly related to the processes of development and implementation of digital computer technologies in all areas of economic production and consumption. As a rule, it covers the area of providing online services and goods, namely electronic payment services and electronic commerce, Internet commerce and the Internet of Things (IoT - Internet of Things), crowdfunding, Internet banking and more. Among the latest digital technologies, which act as a platform for digitalization and the digital economy, the following are distinguished: Big Data technologies, the development of cloud services and artificial intelligence (neural networks), smart technologies and location technologies, the Internet of things, as well as the industrial Internet of things (IIoT - Industrial Internet of Things), 3D printing (Pereira \& Romero, 2017; Singh, 2005).

Digitalization and accessibility of infrastructure ensures full interaction of participants in economic activities. The distinctive features of digital economy include the presence of personalized service models, as well as developed economy of joint consumption and sharing services.

Digitalization processes are especially relevant for the service sector. Trading and transport companies, tourism and hospitality industry enterprises, catering enterprises were given the opportunity to expand their target audience and reach, improve service quality, and develop at an accelerated pace, given that in the global digital economy those companies will benefit whose arsenal involves a greater number and the quality of digital platforms.

A study by the reveals an annual growth of $16.8 \%$ in the global cost of digital transformation, which amounted to 2.1 trillion International Data Corporation US dollars in 2019 (International Data Corporation, 2019).

The Boston Consulting Group estimates that the digital economy will reach 16 trillion US dollars by 2035.A significant part of digitalization is in the sphere of consumption (services, online trading, offline shopping and online search) - 63 billion US dollars, in which the Internet of things plays a huge role. The development of this segment cannot be considered outside the global trends of digital transformation. By 2025, the annual contribution of the Internet of things to the global economy can range from 4 to 11 trillion US \$ (Ruan, Tsai, Zhang, \& Zheng, 2017).

Kazakhstan has begun work on digitizing the tourism sector as part of general digitalization. The State program Digital Kazakhstan was launched in December, 2017 by accepting the Decree No. 827 of the Government of the Republic of Kazakhstan. This is an important comprehensive program that is aimed at improving the living standards of every citizen of the country through in virtue of digital technologies. The main objectives of the Program include accelerated pace of economy development in the Republic of 
Kazakhstan and improved quality of life of its citizens, as well as creation of favorable conditions which will foster the transition of the economy to a new path of digital economy. The state program is designed for the period between 2018-2022 and covers five key areas:

1. "Digitalization of industries" - the transformation of traditional sectors of the economy using breakthrough technologies and opportunities that will increase labor productivity and lead to an increase in capitalization.

2. "Transition to the digital state" - the transformation of the state's infrastructure to provide services to the public and business, anticipating their needs.

3. "Implementation of the Digital Silk Road" — the development of high-speed and secure infrastructure for the transfer, storage and processing of data.

4. "Development of human capital" - transformations encompassing the formation of a creative society and the transition to new realities - the knowledge economy.

5. "Creating an innovative ecosystem" - setting up conditions for the development of technological entrepreneurship with sustainable links between business, the scientific field and the state, as well as the introduction of innovations in production(the Government of the Republic of Kazakhstan, 2017).

Summarizing the digitalization of tourism and hospitality in the Republic of Kazakhstan and the experience of those countries that are already implementing the Industry 4.0 concept in this industry, the model of Tourism 4.0 digital platform for the tourism and hospitality industry of the Republic of Kazakhstan is shown in Figure 1 (Roblek, Meško, \& Krapež, 2016; Zupan Korže, 2019).

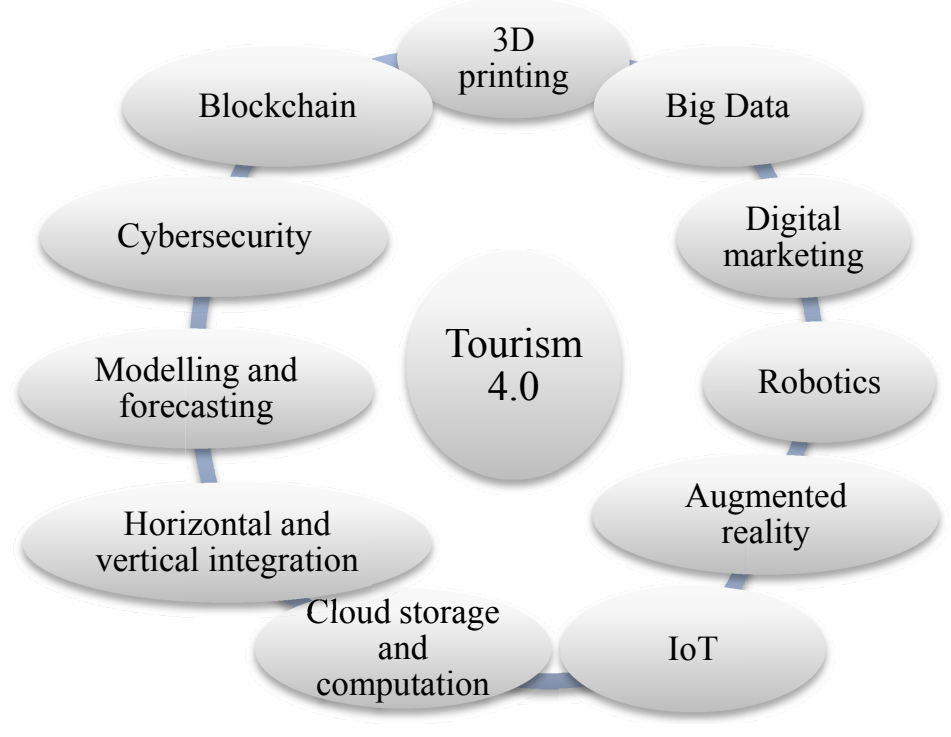

Figure 1. The model of Tourism 4.0 digital platform for the tourism and hospitality industry

Note - compiled by the authors based on source (Zupan Korže, 2019)

The following principles are intrinsic for the model of the digital platform "Tourism 4.0":

- full automation of all links;

- maximum specific weight and significance of R\&D;

- management of all subsystems and links is carried out by an autonomous system using the Internet of things;

- all stages of the tourist product life cycle are provided with the work of functional units in the form of a single interconnected whole, regulated in the online mode by feedback flows.

\section{Methods}

Theoretical and methodological foundations of the paper are based on studies of the prominent local and foreign researchers in the field of tourism development, current state of tourism industry development in the Republic of Kazakhstan, modern trends of digitalization of tourism sector, Government program "Digital Kazakhstan" for 2018-2022. Moreover, data provided by Committee on statistics of Ministry of national economics of the Republic of Kazakhstan, analytical reports of World Economic Forum on Travel and Tourism competitiveness index, IMD World Digital Competitiveness Ranking 2019 report were employed. 
In the course of conducting the research both quantitative and qualitative methods were used, namely: the method of survey, comparative and dynamic analysis, statistical analysis, content analysis.

\section{Results}

According to Google statistics, during the travel planning period, users make about 400 search queries. This huge layer of data is actively used by travel companies in order to influence the decision of the tourists and incline them in favor of a particular itinerary, company and hotel.

$74 \%$ of travelers in the world plan their travel online, which determines the prospects of the market of online services in tourism.

The trend for digitalization in tourism domain forces its market actors to introduce emerging realities to the industry. So, mobile first offers not to focus on conventional versions for desktops and tablets, but on applications for smartphones, while designing booking services. At the same time, there was a significant increase in the demand of travelers generated in virtue of mobile devices: the number of respondents who searched for carpooling services using their smartphone devices increased by more than $62 \%$ in 2019 as compared to 2016, also the growth in share for those who searched for tours via smartphones amounted to $65 \%$. The total share of requests gained from mobile gadgets experienced growth of $40 \%$. Almost $50 \%$ of all those travelers searching through mobile devices made bookings via these devices. Taking all the benefits of the trend requires provision of the customers with convenient services for searching, as well as for making payments for them using their smartphone (Google, 2019).

However, an average domestic traveler still gives tour operators, turning a blind eye to the progress of digitalization, hope for several years of prosperity. According to a global survey of the company Travelport in 2019, tourists prefer to take the total control of their travel experience, which is proven by the fact that $45 \%$ of respondents (plus $9 \%$ as compared to 2018) indicated getting the feeling of frustration when they were not able access their booking details $24 / 7$ on their mobile device("Travelport's Global Digital Traveler Research," 2019).

A similar proportion was recorded with the technophile credentials, which manifested itself in applying voice search to help tackle their travel experience. The most common requests were quires for weather information and live traffic updates. Overall, the global trend of digitalization of the tourism sphere indicates an imminent and global change in the industry.

In Europe, as statistics suggests less than $1 / 3$ of travelers make physical visits to the offices of tour operators. Most tourists planning their itinerary on their own via online platforms. In Kazakhstan, the tourism market is developing taking into account global trends, thus we can conclude, that quite soon the same situation will come. The growth of online sales will take place in two main direction. The first is through selforganization of a tour by purchasing separate flights and accommodation online, the second, through purchasing readily made itineraries from OTAs (Online tour agents). Thus, online sales will replace conventional agencies, some of which will be forced to close, while others will have to reorient their activities to the digital environment.

According to data provided by Booking.com, about $30 \%$ of tourists around the world prefer they travel to be planned by artificial intelligence, which takes into consideration their previous search requests, preferred methods for e-payment, as well as other parameters. $50 \%$ of all respondents do not pay much attention who consults them on the trip details, whether it is a chat bot or a living person, as long as all their desires are taken into account. Most respondents claim that motivation for making a booking increases in cases when all the alternatives suggested by artificial intelligence correspond to the attitudes and desires of the tourists (Booking.com, 2019).

Most of the tourism digitalization tools currently in use are applications. The first digital services for tourists appeared in the early 2000s and were focused on online booking of accommodation and buying tickets: Booking.com - a hotel aggregator made it possible for potential customers to see small hotels around the world, providing them with the widest access to the client base; AirB\&B - repeated the success of Booking.com, creating a new apartment rental market; Uber, Gett - taxi aggregators, attracted a huge number of people to small businesses, gave them the opportunity to earn money using their own car and, at the same time, made taxi services much more affordable (Doucek et al., 2017).

It's hard to imagine a modern journey without using such platforms. With their help, trust ratings are automatically formed between participants, allowing sellers and buyers of goods and services to be combined on the market as soon as possible, including when concluding transactions and making settlements, thereby eliminating intermediary links, minimizing production and exchange processes. 
In general, the use of platforms in the work can significantly strengthen the relationship with the client (to inform and accompany customers on the way), sell more services and increase their price; improve the quality of services (smart phone as a room key, check-in at the hotel via the app, messaging with hotel staff through the app), improve emotional perception (mark where you went and sort photos by places, reminders, directions and instructions at the airport, train station, port and on board); create new opportunities for reaching customers and understanding (notifications, advertising, reviews), integrate with social networks (for representatives of the generation of the 2000s, the share of travel decisions made under the influence of social networks reaches $85 \%$ ) to identify personal preferences of the client and further search for potential customers.

The presence of intense competition and the broadest opportunities in the application market determines the advisability of developing this area in providing conditions for the creation and launch of a new generation of digital platforms (Prokopenko et al., 2019).

In the framework of such trends in 2018, Turkey and Kazakhstan, for example, announced a course towards the development of the Tourism 4.0 concept - countries intend to invest heavily in digital marketing for their tourism industry.

Though, the current position of Kazakhstan in global ranking on ICT readiness is very low. ICT readiness - Information and communication technologies play an extremely important role in raising the national economy, in enhancing its competitiveness. One of the main tasks of the telecommunications industry is the creation of a digital transport environment to support the processes of informatization, the development of modern telecommunications infrastructure and its integration with the infrastructure of other states. The position of Kazakhstan in TTCI reports of 2013, 2015, 2017 and 2019 rankings on the ICT readiness pillar is described in Table 1.

Table 1. Kazakhstan's position in the WEF TTCI-2013, 2015, 2017, 2019 rankings in the context of ICT readiness factors

\begin{tabular}{|l|c|c|c|c|c|c|c|c|}
\hline \multicolumn{1}{|c|}{ Indicator } & \multicolumn{2}{|c|}{2013} & \multicolumn{2}{c|}{2015} & \multicolumn{2}{c|}{2017} & \multicolumn{2}{c|}{2019} \\
\hline \multirow{2}{*}{ ICT readiness } & Rank & Score & Rank & Score & Rank & Score & Rank & Score \\
\cline { 2 - 10 } & 48 & 3,7 & 48 & 4,7 & 52 & 4,9 & 60 & 5,0 \\
\hline ICT use for biz-to-biz transactions & 63 & 5,0 & 64 & 4,8 & 90 & 4,4 & 93 & 4,3 \\
\hline Internet use for biz-to-consumer transactions & 62 & 4,7 & 58 & 4,7 & 53 & 4,7 & 68 & 4,6 \\
\hline Internet users, \% pop. & 62 & 45,0 & 61 & 54,0 & 44 & 70,8 & 46 & 76,4 \\
\hline $\begin{array}{l}\text { Fixed-broadband Internet subscriptions/100 } \\
\text { pop. }\end{array}$ & 46 & 45,0 & 58 & 11,3 & 59 & 13,7 & 62 & 14,2 \\
\hline $\begin{array}{l}\text { Mobile-cellular telephone subscriptions /100 } \\
\text { pop. }\end{array}$ & 68 & 26,3 & 34 & 57,2 & 18 & 156,9 & 20 & 146,6 \\
\hline Mobile network coverage, \% pop. & 11 & 7,4 & 100 & 95,0 & 103 & 96,6 & 102 & 96,6 \\
\hline Mobile-broadband subscriptions / 100 pop. & 29 & 38,4 & 34 & 57,2 & 38 & 73,1 & 58 & 76,6 \\
\hline Quality of electricity supply & 29 & 155,7 & 77 & 4,7 & 80 & 4,5 & 82 & 4,8 \\
\hline Note-compiled by the authorsbased on sources (Schwab, 2019) & & & & & & \\
\hline
\end{tabular}

\section{Discussions}

The data provided indicates on weak Kazakhstan's position in terms of ICT readiness, which lowered for -12 positions (60th place in 2019) during the period of 4 consecutive reports on TTCI prepared by WEF biannually.

Out of 8 constituting individual indicators only two had positive changes, namely: Mobile-cellular telephone subscriptions per 100 citizens ( +48 points, ranking 20th in 2019), and percentage of Internet users $(+16$ points, ranking 46th in 2019$)$.

The rest 6 indicators went through deterioration of different extent. The most negative shift was registered in Mobile network coverage (-91 points ranking 102d out of 140 other countries in 2019). The indicator is calculated as percentage of total population covered by a mobile network system, based on International Communication Union data.

The second most worsened indicator is Quality of electricity supply (-53 points ranking 82th in the world). According to the Executive Opinion Survey the electricity supply in Kazakhstan is not reliable and can be characterized as having interruptions and voltage fluctuations. 
ICT use for biz-to-biz transactions is not sufficient as well - 30 points, ranking 93d in the TTCI 2019. The indicator represents the extent to which enterprises use ICT in transactions with other business entities, sourcing from the Executive Opinion Survey.

Fixed-broadband Internet subscriptions indicator has also worsened but for -16 points ranking $62 \mathrm{nd}$. The indicator refers to the total subscriptions to high-speed access to the TCP/IP (public Internet) connection with the minimal speed of $256 \mathrm{~kb} / \mathrm{s}$.

The next indicator, which reveals negative trend is the Mobile-broadband subscriptions (number of active SIM cards accessing the Internet at the speed not less than $512 \mathrm{~kb} / \mathrm{s}$, got worse on -29 points ranking $58^{\text {th }}$ in 2019.

And the last, but not least is the indicator of Internet use for biz-to-consumer transactions, which worsened to -6 points, ranking $68^{\text {th }}$ in 2019 . This indicator refers to the latest global trend on moving the whole process of purchase online. To become more competitive a certain work should be done in this regard.

To sum up, in Kazakhstan the amount of Mobile-cellular telephone subscriptions has increased, as well the number of Internet users, meanwhile the percentage of Mobile network coverage along with Fixed and Mobile broadband Internet subscriptions has decreased compared to other countries in the ranking.

The results of the analysis of a group of factors revealed the presence of both positive and negative correlation between the resulting indicator of ICT readiness and other sub-indices (Table 2).

Table 2. Correlation between the resulting indicator of ICT readiness and other sub-indices

\begin{tabular}{|l|r|}
\hline & Correlation on rank \\
\hline ICT readiness & 1,00 \\
\hline ICT use for biz-to-biz transactions & 0,86 \\
\hline Internet use for biz-to-consumer transactions & 0,59 \\
\hline Internet users, \% pop. & $-0,76$ \\
\hline Fixed-broadband Internet subscriptions/100 pop. & 0,67 \\
\hline Mobile-cellular telephone subscriptions /100 pop. & $-0,63$ \\
\hline Mobile network coverage, \% pop. & 0,48 \\
\hline Mobile-broadband subscriptions/100 pop. & 0,98 \\
\hline Quality of electricity supply & 0,54 \\
\hline Note - compiled by the authors & \\
\hline
\end{tabular}

The strongest correlation was found between Mobile-broadband subscriptions $(0,98)$, ICT use for bizto-biz transactions $(0,86)$.

\section{Conclusions}

Thus, the analysis of ICT readiness of Kazakhstan in providing its competitiveness as a tourist destination allows us to come to a conclusion that the main limiting factors include insufficient Mobile network coverage, use of ICT both for business tobusiness and business to customers transactions.

Improving and strengthening positions of Kazakhstan in this regard will lead to obtaining better positions on the global tourism arena, increase the influx of tourist to Kazakhstan and facilitated tourism industry development as a whole.

Analyzing the above, we can conclude that the implementation of the State program Digital Kazakhstan until 2025 will allow us to begin to address a number of fundamental problems of the tourism industry in the context of its digitalization, which did not enjoy special attention earlier. On this basis, tourism development can enter a new stage of significant intensification, which will ultimately have a significant positive impact on the country's economy.

\section{References}

Being digital. (1995). Choice Reviews Online. Retrieved from https://doi.org/10.5860/choice.32-6277

Booking.com. (2019). Booking.com Predicts the Top Travel Trends for 2020. globalnews.booking.com. Retrieved from https://globalnews.booking.com/bookingcom-predicts-the-top-travel-trends-for-2020/

Brits, A., \& Cabolis, C. (2019). IMD World Digital Competitiveness Ranking 2019. IMD World Competitiveness Center. Retrieved from https://doi.org/10.1080/0144287042000208233 
Doucek, P., Fischer, J., \& Novotný, O. (2017). Digital economy. IDIMT 2017: Digitalization in Management, Society and Economy - 25th Interdisciplinary Information Management Talks. Retrieved from https://doi.org/10.29322/ijsrp.9.12.2019.p9650

Google. (2019). Travel planning statistics. thinkwithgoogle.com. Retrieved from https:/www.thinkwithgoogle.com/data/travel-planning-statistics/

International Data Corporation. (2019). The Growth in Connected IoT Devices Is Expected to Generate 79.4ZB of Data in 2025, According to a New IDC Forecast.

Negroponte, N. (2010). From being digital to digital beings. IBM Systems Journal. Retrieved from https://doi.org/10.1147/sj.393.0417

Pereira, A.C., \& Romero, F. (2017). A review of the meanings and the implications of the Industry 4.0 concept. Procedia Manufacturing. Retrieved from https://doi.org/10.1016/j.promfg.2017.09.032

Prokopenko, O., Larina, Y., Chetveryk, O., Kravtsov, S., Rozhko, N., \& Lorvi, I. (2019). Digital-toolkit for promoting tourist destinations. International Journal of Innovative Technology and Exploring Engineering. Retrieved from https://doi.org/10.35940/ijitee.L3745.1081219

Roblek, V., Meško, M., \& Krapež, A. (2016). A Complex View of Industry 4.0. SAGE Open. Retrieved from https://doi.org/10.1177/2158244016653987

Ruan, F., Tsai, R., Zhang, K., \& Zheng, T. (2017). Year 2035: 400 Million Job Opportunities in the Digital Age. imagesrc.bcg.com. Retrieved from https://image-src.bcg.com/Images/BCG_Year-2035_400-Million-Job-OpportunitiesDigital Age_ENG_Mar2017_tcm52-153963.pdf

Schwab, K. (2019). The Travel \& Tourism Competitiveness Report 2019 Travel and Tourism at a Tipping Point. www3.weforum.org. Retrieved from http://www3.weforum.org/docs/WEF_TTCR_2019.pdf

Singh, V.P. (2005). Digital Economy : Impacts, Influences and Challenges Digital Economy. In Challenges.

Statistics Committee of the Ministery of National Economy of the Republic of Kazakhstan. (2019). Statistics of tourism. stat.gov.kz. Retrieved from https://stat.gov.kz/official/industry/22/statistic/5

Tashenova, L., Babkin, A.V., \& Mamrayeva, D.G. (2019). Digital transformation of industrial production in the context of Industry 4.0. Bulletin of the Karaganda University. Economy Series, № 4(96), 154-162. Retrieved from https://economy-vestnik.ksu.kz/apart/2019-96-4/18.pdf

The Government of the Republic of Kazakhstan (2017) The State program Digital Kazakhstan, dated December 12 , 2017, No. 827 Retrieved from http://www.akorda.kz/upload/media/files/a0632264810b20c36ed2a4f55d095ad2.docx

Travelport. (2019). Travelport's Global Digital Traveler Research. marketing.cloud.travelport.com. Retrieved from https://marketing.cloud.travelport.com/Global-Digital-Traveler-Research-2019

Zupan Korže, S. (2019). FROM INDUSTRY 4.0 TO TOURISM 4.0. Innovative Issues and Approaches in Social Sciences. Retrieved from https://doi.org/10.12959/issn.1855-0541.iiass-2019-no3-art3

\section{К.П. Мусина, Д.Г. Мамраева, М. Леманович}

\section{Қазақстанның туристік индустриясындағы цифрландыру}

\section{Аңдатпа}

Maқ̧cambl: Туризм индустриясы әртүрлі делдалдық схемалармен сипатталып, Интернет-технологияларды қолдану қажеттілігі осында артып келе жатқандықтан, мақала қазіргі кезеңде Қазақстандағы туристік индустрияны дамыту үшін Интернет-технологияларды қолдану қажеттілігін негіздейді. Атап айтқанда, авторлар цифрлық технологиялардың туризм саласына әсер ету ерекшеліктерін және сандық технологиялардың саланың бәсекеге қабілеттілігін арттыруға қосқан үлесін шектейтін қазіргі проблемаларды зерттеуді мақсат етеді.

Әдісі: Ағымдағы зерттеу үшін статистикалық талдау, мазмұнды талдау сияқты жалпы ғылыми әдістер қолданылған.

Kорытынды: Мақалада цифрлық экономика дәуіріндегі туристік индустрияны цифрлық түрлендірудің негізгі бағыттары сипатталған, сонымен қатар демалыс және саяхаттау орындары туралы толық ақпарат беру арқылы туристердің білімдерін тереңдетуге арналған туристік индустрия үшін цифрлық трансформацияның артықшылықтары көрсетілген; ақпаратты, басқаруды және әкімшілік процестерді енгізу және шығару уақытын қысқарту.

Тұжырымдама: Мақалада Қазақстандағы туризм саласының қазіргі жағдайы талданған, қазақстандық туризм индустриясы контексіндегі АКТ дайындығының нәтижелері келтірілген. Цифрландырудың осы салаға перспективалық әсері де қарастырылған.

Kiлm сөздер: цифрландыру, туризмді дамыту, АКТ, Қазақстан, туризм индустриясы, Tourism 4.0, TTCI. 


\section{К.П. Мусина, Д.Г. Мамраева, М. Леманович \\ Цифровизация в индустрии туризма Казахстана}

\section{Аннотация}

Цель: В статье обоснована необходимость использования интернет-технологий для развития индустрии туризма Казахстана на современном этапе, поскольку индустрия туризма характеризуется разнообразными посредническими схемами, в силу чего потребность в использовании интернет-технологий здесь возрастает. В частности, авторы преследуют цель - исследовать особенности влияния цифровых технологий на сферу туризма и текущие проблемы, ограничивающие вклад цифровых технологий в повышение конкурентоспособности отрасли.

Memoдbl: Для проведения текущего исследования были использованы такие общенаучные методы, как статистический анализ, контент-анализ.

Pезультаты: В статье описаны ключевые области цифровой трансформации индустрии туризма в эпоху цифровой экономики, а также показаны преимущества цифровой трансформации для индустрии туризма, которые призваны углубить знания туристов на основе предоставления подробной информации о местах отдыха и путешествий; сокращение времени на вход и выход информационных, управленческих и административных процессов.

Bblвoдbl: В статье проанализировано текущее состояние туристического сектора в Казахстане, представлены результаты проведенного анализа готовности ИКТ в контексте казахстанской индустрии туризма. Также рассмотрено перспективное влияние цифровизации на эту отрасль. TTCI

Ключевье слова: цифровизация, развитие туризма, ИКТ, Казахстан, туристическая отрасль, Туризм 4.0,

\section{References}

Being digital // Choice Reviews Online. — 1995. — (https://doi.org/10.5860/choice.32-6277).

Booking.com Predicts the Top Travel Trends for 2020 // Booking.com. — 2019. — (https://globalnews.booking.com /bookingcom-predicts-the-top-travel-trends-for-2020/).

Brits A. IMD World Digital Competitiveness Ranking 2019 / A. Brits, C. Cabolis. — IMD World Competitiveness Center. — 2019. — (https://doi.org/10.1080/0144287042000208233).

Doucek P. Digital economy [Text] / P. Doucek, J. Fischer, \& O. Novotný // IDIMT 2017: Digitalization in Management, Society and Economy — 25th Interdisciplinary Information Management Talks. — 2017. — (https://doi.org/10.29322/ijsrp.9.12.2019.p9650).

Google. Travel planning statistics. — 2019. — (https://www.thinkwithgoogle.com/data/travel-planning-statistics/).

International Data Corporation. The Growth in Connected IoT Devices Is Expected to Generate 79.4ZB of Data in 2025, According to a New IDC Forecast. - 2019.

Negroponte N. From being digital to digital beings / N. Negroponte // IBM Systems Journal. — 2010. (https://doi.org/10.1147/sj.393.0417).

Pereira A.C. A review of the meanings and the implications of the Industry 4.0 concept / A.C. Pereira, F. Romero // Procedia Manufacturing. — 2017. — (https://doi.org/10.1016/j.promfg.2017.09.032).

Prokopenko O. Digital-toolkit for promoting tourist destinations / O. Prokopenko, Y. Larina, O. Chetveryk. S. Kravtsov, N. Rozhko, I. Lorvi // International Journal of Innovative Technology and Exploring Engineering. 2019. - (https://doi.org/10.35940/ijitee.L3745.1081219).

Roblek V. A Complex View of Industry 4.0. / V. Roblek, M. Meško, \& A. Krapež // SAGE Open. 2016. — (https://doi.org/10.1177/2158244016653987).

Ruan F. Year 2035: 400 Million Job Opportunities in the Digital Age / F. Ruan, R. Tsai, K. Zhang, T. Zheng. — 2017. — (https://image-src.bcg.com/Images/BCG_Year-2035_400-Million-Job-Opportunities-Digital). Age_ENG_Mar 2017_tcm52-153963.pdf

Schwab K. Travel and Tourism at a Tipping Point / K. Schwab // The Travel \& Tourism Competitiveness Report 2019. — 2019. - (http://www3.weforum.org/docs/WEF_TTCR_2019.pdf).

Singh V.P. Digital Economy: Impacts, Influences and Challenges Digital Economy [Text] / V.P. Singh // In Challenges.- 2005

Statistics of tourism // Statistics Committee of the Ministery of National Economy of the Republic of Kazakhstan. 2019. - (https://stat.gov.kz/official/industry/22/statistic/5).

Tashenova L. Digital transformation of industrial production in the context of Industry 4.0. [Text] / L. Tashenova, A.V. Babkin, D.G. Mamrayeva // Bulletin of the Karaganda University. Economy Series. — 2019. — № 4(96). — P. 154-162. — (https://economy-vestnik.ksu.kz/apart/2019-96-4/18.pdf).

The State program Digital Kazakhstan [Text]: The Government of the Republic of Kazakhstan, dated December 12 , 2017 No. 827. — 2017. — (http://www.akorda.kz/upload/media/files/a0632264810b20c36ed2a4f55d095ad2.docx). 
Travelport's Global Digital Traveler Research / Travelport. — 2019. — (https://marketing.cloud.travelport.com/GlobalDigital-Traveler-Research-2019).

Zupan Korže S. FROM INDUSTRY 4.0 TO TOURISM 4.0. [Text] / S. Zupan Korže // Innovative Issues and Approaches in Social Sciences. — 2019. — (https://doi.org/10.12959/issn.1855-0541.iiass-2019-no3-art3). 